\title{
Notes
}

\section{A Jurisprudential Problem in the Submerged Lands Cases: International Law in a Domestic Dispute}

No international judicial body has permanent, general jurisdiction to issue binding decisions. ${ }^{1}$ National courts therefore play an important role in developing international law. ${ }^{2}$ In addition to resolving international disputes, national courts sometimes apply international legal rules to domestic controversies. ${ }^{3}$ In applying international law, however, United States courts have not always been sensitive to the different policy concerns appropriate to the international and national settings.

The history of litigation over the boundary between federal and state ownership of submerged lands adjacent to the United States coast illustrates the application of international law to a domestic controversy. In order to interpret the Submerged Lands Act (Act), ${ }^{4}$ which grants submerged offshore lands to the maritime states, the Supreme Court has invoked international law, as codified in the Convention on the Territorial Sea and the Contiguous Zone (Convention). ${ }^{5}$ This Note challenges the

1. See N. LEECH, C. Oliver, \& J. SWEenEY, CASES AND MATERIALS ON THE INTERNATIONAL LEGAL SYSTEM 57-87 (1973) (describing international tribunals); J. STARKE, AN INTRODUCTION TO INTERNATIONAL LAW 53-57 (8th ed. 1977) (describing international judicial bodies). Decisions of the International Court of Justice (ICJ) have no binding force "except between the parties and in respect of [a] particular case." STATUTE OF THE INTERNATIONAL COURT OF JUSTICE art. 59. The General Assembly, the Security Council, and other United Nations organs or specialized agencies may reguest advisory opinions from the ICJ. U.N. CHARTER art. 96.

2. Federal court jurisdiction to apply international law is created by statute in some cases. See, e.g., Alien Tort Claims Act, 28 U.S.C. $\$ 1350$ (1976) (giving federal courts jurisdiction over civil actions by aliens for torts committed in violation of international law). More commonly, international law is incorporated as a matter of federal common law. See The Paquete Habana, 175 U.S. 677, 700 (1900) (United States courts can determine international law in deciding relevant questions); The Nereide, 13 U.S. (9 Cranch) 388, 423 (1815) (in absence of act of Congress, courts are bound by international law, which is part of law of land). The supremacy clause of the United States Constitution binds courts to uphold treaties to which the United States is party. U.S. CONST. art. VI, cl. 2 ("IA]ll Treaties made, or which shall be made, under the Authority of the United States, shall be the supreme Law of the Land; and the Judges in every State shall be bound thereby . . . .") But cf. Reid v. Covert, 354 U.S. 1, 18 (1957) (later enacted statute conflicting with treaty renders treaty null).

3. The International Law Commission selected the laws of territorial waters for "codification" in 1949. Report of the ILC, 4 GAOR Supp. (No. 10) at 3, U.N. Doc. A/925 (1949).

4. 43 U.S.C. $\S \S 1301-1315$ (1976).

5. Convention on the Territorial Sea and the Contiguous Zone, opened for signature Apr. 29, 1958, 15 U.S.T. 1606, T.I.A.S. No. 5639 (effective Sept. 10, 1964) [hereinafter cited without cross- 
wisdom of this domestic application of international law.

The delimitation of offshore zones adjacent to the United States coast involves two separate issues: the domestic question of determining the boundary between federal and state ownership of offshore lands, and the international question of determining the national boundary of the United States as against other nations. Since the domestic question does not implicate the nation's foreign affairs, it should be resolved without resort to international law. In addition, reliance on international legal rules frustrates consideration of the distinctive features of the domestic question. Finally, to the extent that domestic concerns do smuggle themselves into Court decisions purporting to apply international law, the Court makes a distorted contribution to the development of international law.

\section{The Submerged Lands Controversy}

For over thirty years, the federal government and the maritime states have been engaged in a legal dispute over ownership of lands lying under the waters directly adjacent to the nation's shore. ${ }^{6}$ The Supreme Court has sometimes treated this dispute as a problem in relations between the states and the federal government. ${ }^{7}$ At other times, it has treated the dispute as a United States foreign policy problem for which the federal executive should be primarily responsible. ${ }^{8}$ In 1965 , the Court decided to resolve the controversy through the application of international law, implying that the dispute was primarily a foreign policy issue."

\section{A. Submerged Lands and the Territorial Sea}

International law ${ }^{10}$ measures most ocean zones in terms of given distances from a nation's "baseline" (or "coastline"), a legal construct that is

reference as Territorial Sea Convention]. The United States ratified the Convention on March 24, 1961. The Convention was one of four agreements signed at the United Nations Conference on the Law of the Sea held at Geneva in 1958. See note 10 infra (listing agreements).

6. See United States v. California, 447 U.S. 1 (1980); United States v. California, 332 U.S. 79 (1947).

7. See E. BARTley, ThE TIDELANDS OIL CONTROVERSY 6 (1953) (suggesting that submerged lands cases would be viewed as significant in development of federalist relations); pp. 1659-60 infra.

8. See Charney, Judicial Deference in the Submerged Lands Cases, 7 VAND. J. TRANSNAT'L L. 383, 413-54 (1974).

9. United States v. California, 381 U.S. 139, 165 (1965).

10. Customary international law has long divided ocean space into zones over which coastal nations exercise varying degrees and types of authority. Much of this law is now codified as a result of the United Nations Conference on the Law of the Sea. That Conference produced four conventions in 1958. See Territorial Sea Convention; Convention on the Continental Shelf, opened for signature Apr. 29, 1958, 15 U.S.T. 471, T.I.A.S. No. 5578 (effective June 10, 1964); Convention on the High Seas, opened for signature Apr. 29, 1958, 13 U.S.T. 2312, T.I.A.S. No. 5200 (effective Sept. 30, 1962); Convention on Fishing and Conservation of the Living Resources of the High Seas, opened for signature Apr. 29, 1958, 17 U.S.T. 138, T.I.A.S. No. 5969 (effective Mar. 20, 1966). 
sometimes, but not always, similar to the physical shoreline." "Inland waters," defined as being within the baseline, may include a nation's harbors, ports, rivers, bays, and gulfs. ${ }^{12}$ A coastal nation exercises full sovereign rights within its inland waters. ${ }^{13}$ Directly seaward of the baseline lies a nation's territorial sea, in which that nation has most of the rights of sovereignty but must allow the right of innocent passage to foreign vessels. ${ }^{14}$ Today a twelve-mile territorial sea is recognized in customary international law. ${ }^{15}$ The United States currently claims a three-mile territorial sea, although that limit is likely to be extended to twelve miles at the conclusion of the Third United Nations Conference on the Law of the Sea. ${ }^{16}$ International law also recognizes a series of zones seaward of the territorial sea, including the contiguous zone, ${ }^{17}$ the continental shelf, ${ }^{18}$

11. See Territorial Sea Convention arts. 3-13 (prescribing methods of delimiting baseline in international law); Pearcy, Geographical Aspects of the Law of the Sea, 49 ANNALS ASS'N AM. GEOGRAPHERS 1, 5-6 (1959) (baseline is key to delineation of zones of water and submerged lands off coast).

12. The extent of inland waters will vary depending on whether coastal features such as bays, island fringes, and artificial structures, including piers and harborworks, are included within inland waters. See Territorial Sea Convention arts. 3-13.

13. See id. art. 1.

14. Id. art. 14 .

15. See Oxman, The Third United Nations Conference on the Law of the Sea: The Eighth Session (1979), 74 AMI. J. INT'L L. 1, 9-10 (1980). The Third United Nations Conference on the Law of the Sea has been unable to reach agreement on the breadth of the territorial sea. N.Y. Times, Mar. 14,1981 , at 3, col. 2. States with strong navies and advanced technical capabilities have tended to urge the world community to adopt relatively narrow territorial seas because wide zones would restrict the ocean area open to navigation and resource exploitation. See S. SWARZTRAUBER, THE THREE-MILE LIAIT OF TERRITORIAL SEAS 236-44 (1972) (Britain and, after World War II, United States have been foremost among supporters of narrow territorial seas).

The First and Second United Nations Conferences on the Law of the Sea were unable to establish the breadth of the territorial sea. [1960] U.N.Y.B. 542-44. The ninth session of the Third Conference concluded in Geneva in August 1980. Among the provisions of the emerging treaty are a grant of exclusive mineral, oil, and fishing rights to maritime countries out to 200 miles and free passage in all straits. See N.Y. Times, Aug. 31, 1980, $\S 4$, at 16, col. 1. By contrast, third world nations have urged, and some have proclaimed, territorial seas up to 200 miles off their own coasts. See B. BUZAN, SEABED POLITICS 118 (1976).

16. At the Third United Nations Conference on the Law of the Sea, the United States agreed to accept a twelve-mile territorial sea if provision were made for the right of passage in all straits used for international navigation. U.S. Draft Articles on Territorial Sea, Straits, and Fisheries, Submitted to U.N. Seabeds Committee, U.N. Doc. A/AC.138/SC.II/L.4, reprinted in 10 INT'L LEGAL MATERIALS 1013, 1018 (1971). See generally Reisman, The Regime of Straits and National Security: An Appraisal of International Lawmaking, 74 AM. J. INT'L L. 48 (1980) (analysis of issues involved in passage of foreign vessels through straits in territorial waters). More recently, the Reagan administration has made the speedy culmination of the Conference unlikely by initiating a comprehensive review of all conclusions reached in the negotiations to date. N.Y. Times, Mar. 14, 1981, $\$ \mathrm{~A}$, at 3, col. 2.

17. The Territorial Sea Convention provides for a contiguous zone, seaward of the territorial sea, over which a nation can exercise certain forms of control and jurisdiction without altering the character of the zone as part of the high seas. Territorial Sea Convention art. 24. The zone can extend up to twelve miles from a nation's baseline. Id.

18. The term "continental shelf" in international law denotes the seabed and subsoil seaward of the territorial sea to a depth of 200 metres or to the point where exploitation of the shelf becomes impossible. Convention on the Continental Shelf, opened for signature Apr. 29, 1958, art. 1, 15 U.S.T. 471, T.I.A.S. No. 5578 (effective June 10, 1964). Thus, unlike most other ocean zones, the continental shelf is not measured in terms of a given distance from a nation's baseline. 
and the exclusive economic zone. ${ }^{19}$ The high seas ${ }^{20}$ lie beyond the areas of national control and jurisdiction.

\section{B. Development of the Submerged Lands Controversy}

Until the late $1930 \mathrm{~s}$, Congress and the federal executive assumed that the states held title to submerged lands adjacent to their coasts. ${ }^{21}$ Beginning in 1937, however, the administration sought legislation declaring submerged offshore lands to be part of the federal domain. ${ }^{22}$ These efforts failed. ${ }^{23}$ After the Second World War, members of Congress introduced various bills quitclaiming or assigning title to submerged lands to coastal states. ${ }^{24}$

19. The Informal Composite Negotiating Text of the Third United Nations Conference on the Law of the Sea art. 57, U.N. Doc. A/Conf.62/WP.10 \& Add. 1 (1977), defines the exclusive economic zone as extending not more than 200 nautical miles beyond a nation's baseline. A coastal nation has rights to explore and exploit natural resources in the seabed, subsoil, and superjacent waters of the zone. Id. at 56. The United States claims a 200-mile exclusive fishery zone. Fishery Conservation and Management Act of 1976, §§ 3(3), 201(a), 16 U.S.C. §§ 1802(3), 1821(a) (1976).

20. The Convention on the High Seas, opened for signature Apr. 29, 1958, art. 1, 13 U.S.T. 2312, T.I.A.S. No. 5200 (effective Sept. 30, 1962), defines high seas as all ocean areas not included in the territorial seas or inland waters of a nation. On the high seas, all nations have freedom of the seas; no nation can appropriate these waters or the lands beneath them as national territory. The Convention on the High Seas enumerates specific protected freedoms in the high seas, including the freedoms to navigate and to fish. Id. art. 2.

21. See E. BARTLEY, supra note 7, at 95-101, 122-34 (until 1937, Congress did not regard areas below low-water mark as federal public lands, and Departments of Justice, Interior, and War made no claims of federal title over submerged lands). Secretary of the Interior Harold Ickes asserted in 1933 that title to lands below the high-water mark "inures to the States within which [such submerged lands] are situated," being "incidental to the sovereignty of the state." Metcalfe, The Tidelands Controversy: $A$ Study in Development of a Political-Legal Problem, 4 SYRACUSE L. REV. 39, 41 (1952) (citing Hearings on S.J. Res. 83 and S.J. Res. 92 before the Senate Comm. on Public Lands and Surveys, 76th Cong., 1st Sess. 172 (1939)).

The Supreme Court has consistently held that states have title to inland waters. See, e.g., The Abby Dodge, 223 U.S. 166 (1912) (right of state to control sponge fishing); Manchester v. Massachusetts, 139 U.S. 240 (1891) (right of states to control fishing). Between the American Revolution and World War II most maritime states asserted jurisdiction over the marginal ocean belt out to at least three miles. See Breeden, Federalism and the Development of the Outer Continental Shelf Mineral Resources, 28 STAN. L. REV. 1107, 1111 n.14 (1977). However, the Court did not have to decide where a state's title ended until the 1940s. See pp. 1655-56 infra (discussing California $I$ ).

22. See United States v. Louisiana, 363 U.S. 1, 6 n.4 (1960) (listing bills introduced in Seventyfith Congress (1937-1938) and Seventy-sixth Congress (1939) confirming federal government's rights to submerged lands under marginal seas). The most prominent of these bills was S.J. Res. 208, 75th Cong., 3d Sess. (1937), introduced by Senator Nye of North Dakota. This bill was passed by the Senate but not the House. See Metcalfe, supra note 21, at 44.

23. See Metcalfe, supra note 21 , at 45-51. When World War II intervened, legislative interest in declaring offshore lands to be federal property gave way to more pressing concerns.

24. Nineteen similar bills were introduced in 1945. See id. at 51. Forty-six of the forty-eight states' attorneys general gave support to legislation quitclaiming submerged lands to the states. See E. BARTLEY, supra note 7, at 148. States' representatives feared that federal control over oil in the submerged lands might mean the federal government could control products other than oil as well as present and future installations. Id. at 149.

In 1946, President Truman vetoed H.J. Res. 225, 79th Cong., 2d Sess. (1946), which quitclaimed submerged lands in the maritime belt to the adjacent states. See 1946 PUB. PAPERS 371-72. The President argued that since United States v. California, 332 U.S. 19 (1947), was pending, "[t]he Congress is not an appropriate forum to determine the legal issue now before the Court." 1946 PUB. 
In 1945, President Truman issued the Truman Proclamation, in which the United States asserted "jurisdiction and control" over the natural resources of the seabed and subsoil of the continental shelf. ${ }^{25}$ A White House press release characterized the Proclamation as establishing United States jurisdiction only "from an international standpoint." ${ }^{26}$ An important motivation for issuing the Proclamation, however, was to establish federal control vis-a-vis the states. In fact, the Proclamation was of doubtful foreign policy value because at the time only American and Americandominated companies were capable of exploiting resources on the outer continental shelf. ${ }^{27}$ Truman wanted to link the international justification with the domestic claims in order to give more credence to federal claims against the states. ${ }^{28}$

Several weeks after the Truman Proclamation, the federal government filed a complaint in trespass against California in the Supreme Court. ${ }^{29}$ It asked for a declaration that the federal government and not the state had "rights" and "powers" over the submerged lands off the California shore. ${ }^{30}$ In California I, announced two years later, the court held that the Federal Government had full dominion over submerged lands. ${ }^{31}$ The

\section{PAPERS 371-72.}

25. Pres. Proc. No. 2667, 3 C.F.R. 67 (1943-1948 Compilation), reprinted in 59 Stat. 884 (1945). The Proclamation claimed an area out to a depth of 100 fathoms. Id. The Secretary of the Interior stated that this area extended between 20 and 250 miles from the coastline on the east coast and between 1 and 50 miles on the west coast. $4 \mathrm{M}$. WHITEMAN, DIGEST OF INTERNATIONAL LAW 760 (1965) (citing [1945] SEC. INTERIOR ANN. REP. at ix-x). The total size of this area was almost three times the size of France. 1 A. SHALOWITZ, SHORE AND SEA BOUNDARIES 188 (1962). The 100 fathoms figure had little to do with the geographical definition of the continental shelf, but had practical importance; it was presumed to be beyond the depth of feasible resource exploitation for the foreseeable future. De Jouvenal, An Economic View of Marine Problems, in THE TIDES of CHANGE 4, 5 (E. Borgese \& D. Krieger eds. 1975).

26. 13 DEP’T STATE BULl. 484 (1947); see Exec. Order No. 9633, 3 C.F.R. 437 (1943-1948 Compilation).

27. See Borgese, Boom, Doom, and Gloom Over the Oceans: The Economic Zone, The Developing Nations, and the Conference on the Law of the Sea, 11 SAN DIEGO L. REV. 541, 544 (1974).

28. See De Jouvenal, supra note 25, at 6, 11-12 (Department of Interior urged assertion of federal jurisdiction in order to be able to grant concessions to explore offshore area; purported international policy motives are contrary to best interests of United States); Hollick, U.S. Oceans Policy: The Truman Proclamations, 17 VA. J. INT'L L. 23, 30-46 (1976) (discussing activities of Interior and Justice Departments in period preceding Truman Proclamation).

29. See United States v. California, 326 U.S. 688 (1945) (granting motion for leave to file). When it filed this suit, the federal government dropped an carlier suit in which it had asserted its claim to the three-mile belt. See United States v. Pacific W. Oil Co., No. 44-936 (S.D. Cal., filed May 29, 1945).

30. See United States v. California, 332 U.S. 19, 22 (1947).

31. United States v. California, 332 U.S. 19 (1947). California's claim to the disputed marginal belt depended in large part on Pollard's Lessee v. Hagan, 44 U.S. (3 How.) 212 (1845) (states hold navigable tidewaters between high- and low-water marks in trust for people). The California I Court declined to extend Pollard to cover the submerged lands seaward of the low-water mark. 332 U.S. at 30-31.

The Court retained jurisdiction over the California case and has since issued a number of further decrees and opinions: United States v. California, 332 U.S. 804 (1947) (decree following California I); United States v. California, 381 U.S. 139 (1965) (California II) (second major opinion, applying 
Court relied on the need for national powers "of dominion and regulation in the interest of [the nation's] revenues, its health, and the security of its people from wars waged on or too near its coasts. ${ }^{132}$

The authority of the federal government over the conduct of international affairs, however, would not be impeded by state possession of the disputed ocean zones. ${ }^{33}$ Given the paramount rights granted to the federal government by the Constitution, the federal government retains the same responsibility for the security of the submerged lands as it does for the rest of the country. ${ }^{34}$ That responsibility is separate from rights of ownership. Oil in the submerged lands could become the subject of international dispute. ${ }^{35}$ But such disputes might also arise regarding valuable resources squarely within the nation's land territory, and states control property rights in these resources. ${ }^{36}$ The Court confused "property," a domestic law concept, with "sovereignty," an international law concept."

\section{The Submerged Lands Act and California II}

In 1953, in response to the Court's holding that the federal government had dominion over the submerged lands, ${ }^{38}$ Congress passed the Submerged Lands Act. ${ }^{39}$ The Act overturned California $I$ and two subsequent submerged lands decisions $\mathrm{s}^{40}$ by granting each state title to land beneath navi-

Convention for purposes of interpreting Submerged Lands Act); United States v. California, 382 U.S. 448 (1966) (decree following California II); United States v. California, 432 U.S. 40 (1976) (second supplemental decree, identifying with greater particularity boundary line defined in first decree and defining closing lines across entrances to bodies of inland waters and artificial extensions of coastline); United States v. California, 439 U.S. 30 (1978) (third supplemental decree, denying United States title to submerged lands within Channel Islands National Monument and denying California title to areas above mean high-water line of certain islands); United States v. California, 447 U.S. 1 (1980) (California III) (considering whether artificial island complex and certain piers are part of California coastline).

32. 332 U.S. at 33.

33. See id. at 44 (Frankfurter, J., dissenting); Breeden, supra note 21, at 1111 n.14; Charney, supra note 8 , at 448 .

34. See United States v. California, 332 U.S. 19, 44 (1947) (Frankfurter, J., dissenting).

35. Id. at 35 .

36. Id. at 44 (Frankfurter, J., dissenting) (oil deposits no more relevant to question of ownership of submerged lands than uranium deposits inside nation to question of trespass to lands where they lie).

37. Id. at 43-45 (Frankfurter, J., dissenting).

38. The states reacted negatively to the Court's holding. The New England states feared that their fishing rights would be limited, while other states were concerned that the decisions boded ill for the general principle of states' rights. See R. ENGLER, THE POLITICS OF OlL 89 (1961).

39. Pub. L. No. 83-31, 67 Stat. 29 (1953) (codified at 43 U.S.C. $\$ \S 1301-1315$ (1976)). The Outer Continental Shelf Lands Act, Pub. L. No. 83-212, 67 Stat. 462 (1953) (codified at 43 U.S.C. $\$ \S 1331-1356$ (1976)), enacted shortly after the Submerged Lands Act, asserts federal jurisdiction over the outer continental shelf seaward of the lands granted to the states by the Submerged Lands Act; it also authorizes leasing for mineral development, 43 U.S.C. $\$ \S 1334-1339$ (1976).

40. California $I$ was followed by similar cases involving Louisiana and Texas. See United States v. Louisiana, 339 U.S. 699 (1950) (Louisiana I); United States v. Texas, 339 U.S. 707 (1950). 
gable waters" within the state's boundary as it "existed at the time such State became a member of the Union or as heretofore approved by the Congress." ${ }^{\prime 2}$ The grant was limited, however, to three geographical miles from the coastline in the two oceans and to three marine leagues (approximately nine geographical miles) in the Gulf of Mexico (Gulf). ${ }^{43}$ The Act defined "coast line" as "the line of ordinary low water along that portion of the coast which is in direct contact with the open sea and the line marking the seaward limit of inland waters." ${ }^{34}$ The Act did not, however, define "inland waters." 45 Thus the boundaries of the three-mile wide area quitclaimed to the states were not clearly identified by the Act.

Problems of delimiting the federal-state boundary off the shore of California became pressing in the early 1960s when improvements in oil technology permitted oil and gas exploitation at and beyond three miles from the shore. ${ }^{46}$ After California $I$ the Court had appointed a Special Master to establish the boundary between federal and state property. ${ }^{47}$ In California II, decided in 1965, the Supreme Court reviewed the Special Master's report and exceptions to it filed by California and by the federal government. ${ }^{48}$

The Court held that the definition of "internal waters"49 contained in

41. 43 U.S.C. $\S 1311$ (1976). The Act defined "lands beneath navigable waters" to include: (1) lands within a state's boundaries "which are covered by nontidal waters that were navigable . . . at the time such State became a member of the Union, or acquired sovereignty over such lands and waters thereafter, up to the ordinary high water mark," id. §1301(a)(1); (2) lands covered by tidal waters up to the high tide line

and seaward to a line three geographical miles distant from the coast line of each such State and to the boundary line of each such State where in any case such boundary as it existed at the time such State became a member of the Union, or as heretofore approved by Congress, extends seaward (or into the Gulf of Mexico) beyond three geographical miles,

id. $\$ 1301(\mathrm{a})(2)$; and (3) lands that were beneath navigable waters but have been filled in, made, or reclaimed, $i d$. $\$ 1301($ a)(3).

42. Id. $\S 1301(\mathrm{~b})$.

43. Id. The greater distance permitted the Gulf states rested upon claims by Texas and Florida. Texas claimed that the three-league boundary established by the independent Republic of Texas in 1836 was given congressional recognition when Texas became a state. 99 CoNG. REC. 2620 (1953). Florida asserted that the three-league boundary claimed in the state's constitution was approved by Congress when it acquired statehood. Id. at 2622.

44. 43 U.S.C. $\S 1301$ (c) (1976).

45. See United States v. California, 381 U.S. 139, 154 (1965) (legislative history indicates intent "to leave the definition of inland waters to the courts without restriction").

46. See id. at 148 .

47. United States v. California, 334 U.S. 855, 856 (1948).

48. See United States v. California, 381 U.S. 139, 144, 149 (1965).

49. The federal government argued in California II that the Court should apply the definitions of international maritime boundaries supported by the United States at the time of the passage of the Submerged Lands Act. If accepted, this contention would have resulted in a baseline under the Act different from that under international law at the time of the decision. Brief for United States in Answer to California's Exceptions to the Report of the Special Master at 11, United States v. California, 381 U.S. 139 (1965). The federal government's argument in California II was strategic rather than principled. Its position, if accepted, would have resulted in a smaller grant to California. 381 U.S. at 163-64. 
the Convention on the Territorial Sea and the Contiguous Zone ${ }^{50}$ should be used in interpreting the term "inland waters" in the Submerged Lands Act. $^{51}$ The Court reasoned that the Convention provided the "most workable" definitions available. ${ }^{52}$ By applying the Convention in the submerged lands cases, the Court made the definition of inland waters coextensive for international and federal-state purposes. ${ }^{53}$ Thus, the three-mile limits of state ownership and of United States territorial waters were defined as identical. Since 1965, the courts have consistently applied the Convention to resolve submerged lands boundary disputes. ${ }^{54}$

\section{Proper Selection of Law in the Submerged Lands Cases}

The Court's adoption of the Convention represents a unique application of codified international law in order to resolve a domestic dispute. ${ }^{55}$ The framers of the Gonvention intended to develop law for disputes between nations, not disputes in an intranational context. The Court adopted the rule of the Convention because it mistakenly regarded the controversy over federal versus state ownership of offshore lands as a foreign policy problem. This decision has obscured the real issue in this dispute: the conflicting claims of the states and federal government to valuable oil, gas, and other offshore resources. ${ }^{56}$

50. See Territorial Sea Convention arts. 3-13 (setting out rules for delimiting inland waters).

51. United States v. California, 381 U.S. at 165.

52. Id. The Territorial Sea Convention became effective for the United States on September 10, 1964. 1980 U.S. DEP'T OF STATE, TREATIES IN FORCE 318 (1980). But cf. p. 1661 infra (Court stipulated that federal-state boundary would not be affected by future changes in international law).

53. United States v. California, 381 U.S. at 165.

54. See United States v. Alaska, 422 U.S. 184, 188-89 (1975) (discussing status of Cook Inlet as "historic bay"); United States v. Louisiana, 394 U.S. 11, 35 (1969) (Louisiana III) (holding that Louisiana's coastline should be determined through principles of Convention); Alaska v. United States, 353 F.2d 210 (9th Cir. 1965) (holding that California II mandated 24-mile closing line for bays, including bay in question). The rules of the Convention were indirectly at issue in United States v. Maine, 420 U.S. 515, 528 (1975) (holding that Maine and other Atlantic states did not have title to seabed beyond three-mile territorial sea).

The Submerged Lands Act does not apply to all disputes concerning state ownership of offshore areas. See, e.g., Island Airlines, Inc. v. CAB, 352 F.2d 735, 742-43 (9th Cir. 1965) (filights between Hawaiian Islands held to be flights over high seas and, therefore, subject to CAB jurisdiction).

55. The Court had previously applied customary international law to determine boundaries between states within the United States. See Dickinson, The Law of Nations as Part of the Law of the United States (pt. 2), 101 U. PA. L. REV. 792, 821-22 (1953). Whatever the merits of that practice, it differed from the application of the Convention in the submerged lands cases. First, it did not involve codified international law. In addition, interstate boundary determinations did not involve, as do the Court's decisions in the submerged lands cases, a simultaneous determination of a domestic and an international boundary. Further, a controversy between two states within the United States is more analogous to one between nations than is a controversy between a state and the federal government. See id. at 821-22.

56. See Metcalfe, supra note 21, at 39 (rights over oil main factor in submerged lands cases). By the late 1930s, the size of the resources in dispute was recognized as large and potentially enormous; in the late $1940 \mathrm{~s}$, future revenues from the submerged lands areas off the Texas coast were estimated at $\$ 1$ billion. See E. BARTLEY, supra note 7, at 66,79 . Federal-state competition for offshore resources involved not only immediate economic stakes but also concern for the conservation of oil reserves. See 


\section{A. The Domestic Nature of the Controversy}

In fixing rules for delineating the federal-state offshore boundary in California II and later submerged lands cases, the Court should not have considered foreign affairs concerns. In Louisiana $I I^{57}$ for example, decided five years after California $I I$, the question before the court was whether the offshore boundaries of the Gulf states could extend beyond the three-mile territorial sea. Texas and Florida ${ }^{58}$ claimed title to submerged lands out to three marine leagues based on historic claims dating from their admission to the Union. ${ }^{59}$ The federal government claimed that state ownership should be limited to the three-mile territorial sea. Stressing international aspects of the controversy, the national government asserted that its claim was entitled to the deference traditionally owed the executive in foreign affairs. The Court held that Texas and Florida had rights to submerged lands outside the three-mile limit. ${ }^{60}$ The other Gulf states, however, were held to the general three-mile limit. ${ }^{61}$ In explaining this result the Court emphasized the domestic nature of the controversy. "[I]n light of the purely domestic purposes of the Submerged Lands Act, we see no irreconcilable conflict between the Executive policy relied on by the Government and the historical events claimed to have fixed seaward boundaries for some States in excess of three miles."

The Gourt directly confronted the question of whether a state's offshore boundary under the Submerged Lands Act could extend beyond the threemile territorial sea claimed by the executive branch. Dividing the question into two parts, the Court first decided that a state would not contravene international law by exercising rights in submerged lands beyond the territorial sea. ${ }^{63}$ The Court noted that the sort of jurisdiction involved in the

id. at 136. When President Truman vetoed legislation quitclaiming submerged lands to the states in 1946, see note 24 supra, he stressed the national interest in oil resources in the submerged lands from the perspectives of defense and conservation. 1946 PUB. PAPERS 371-72.

57. United States v. Louisiana, 363 U.S. 1 (1960).

58. Five states were defendants in the declaratory judgment action brought by the United States; the Court considered the boundaries of Louisiana, Texas, Mississippi, and Alabama in one opinion, id., and the boundary of Florida in a separate opinion, United States v. Florida, 363 U.S. 121 (1960).

59. See note 43 supra (describing claims).

60. United States v. Louisiana, 363 U.S. 1, 25-26 (1960); United States v. Florida, 363 U.S. 121, 121-29 (1960). The Court granted Florida and Texas a three-marine-league zone for essentially the same historical reasons that Congress gave the Gulf states differential treatment in the Submerged Lands Act. See note 43 supra.

61. United States v. Louisiana, 363 U.S. 1, 85 (1960). Justice Black, in a separate opinion, argued that all of the Gulf states should be granted rights to submerged lands out to three marine leagues. His opinion merits attention because, although he was the author of California $I$, his characterization of the submerged lands controversy changed as a result of the passage of the Submerged Lands Act. See 363 U.S. at 92 (Black, J., concurring and dissenting) (Congress intended Court to establish boundaries on basis of "broad principles of equity" rather than technical legal title).

62. 363 U.S. at 33 (emphasis added).

63. Id. at 30-31. 
Submerged Lands Act is of a "very special and limited character." Exploitation by states of the submerged lands beyond three miles from the coastline would not embarrass the United States in its dealings with other nations. ${ }^{65}$

Second, the Gourt considered whether the right to exploit resources in the submerged lands constituted an assertion of United States sovereignty. ${ }^{66}$ The Court assumed that if resource exploitation represented a claim of sovereignty, it should defer to the federal government's position that state boundaries could not extend beyond the three-mile territorial sea. The Court decided that a state boundary beyond three geographical miles could exist under the Submerged Lands Act, "irrespective of the limit of territorial waters." though it claimed jurisdiction, did not claim sovereignty over the seabed and subsoil of the continental shelf or control of this area. ${ }^{68}$

The Supreme Court also recognized the purely domestic nature of the submerged lands controversy in Alabama v. Texas. ${ }^{69}$ In that decision, upholding the constitutionality of the Submerged Lands Act, the Court relied on the unlimited power of Congress to dispose of federal property and made no mention of international matters. ${ }^{70}$ As the dissent contended, the decision presupposed that the controversy was domestic. Congress obviously could not bestow upon states the international powers of the federal government. ${ }^{71}$ The Submerged Lands Act simply allocated rights of resource exploitation between the states and the federal government.

In sum, the Supreme Court has previously recognized that there would be no international implications if the line defined for purposes of the Submerged Lands Act were seaward of the baseline drawn for international purposes. ${ }^{72}$ The states would be obliged to respect rights of foreign nations under international law in the areas concerned, just as they must respect the right of "innocent passage" ${ }^{\text {"3 }}$ for foreign ships in the territorial

64. Id. at 31. The Court looked to prior State Department positions. Jack B. Tate, Deputy Legal Adviser to the State Department, had testified before a congressional committee that state jurisdiction beyond three miles would not conflict with the conduct of United States foreign affairs or with international law. Id. at 30-31 (citing Submerged Lands: Hearings on S.J. Res. 13, S. 294, S. 107, S. 107 Amendment, S.J. Res. 18, Before the Senate Comm. on Interior and Insular Affairs, 83d Cong., 1st Sess. 1055 (1953) (statement of Jack B. Tate)).

65. 363 U.S. at $30-31$.

66. Id. at 30-36.

67. Id. at 36 .

68. Id. at 35.

69. 347 U.S. 272 (1954).

70. Id. at 273-74.

71. Id. at 279-80 (Black, J., dissenting).

72. This situation is unlikely to arise because the United States will probably soon declare a 12 mile territorial sea. See S. SWARZTRAUBER, supra note 15, at 229-33, 244-48.

73. See Territorial Sea Convention arts. 14-23. 
sea. ${ }^{74}$ As a practical matter, however, confrontation between state jurisdiction and rights of foreign nations recognized by the United States would not occur because the United States claims exclusive jurisdiction and control over natural resources in the subsoil and seabed of the continental shelf. ${ }^{75}$ If the United States declares a twelve-mile territorial sea, $^{76}$ the issue of states' obligations to respect international law in areas beyond the United States territorial sea will be definitively put to rest.

\section{B. The Feasibility of Multiple Baselines}

That the line demarcating the seaward edge of inland waters for purposes of the Submerged Lands Act need not be coextensive with the nation's coastline for international purposes is further suggested by the fact that numerous delimitations of the coastline already exist for different purposes without causing undue confusion. For example, the United States uses an "inland water line" for purposes of regulating navigation." Though similar, that line is not identical with the baseline established to demarcate the landward edge of the territorial sea. ${ }^{78}$

In addition, though the Court proclaimed in California II that it was establishing a single international and federal-state boundary, it stipulated that the federal-state boundary would not be affected by future changes in international law. ${ }^{79}$ The Court concluded that it would be undesirable for the United States to be hampered in developing its foreign policy because of potential repercussions on submerged land ownership. ${ }^{80}$

\section{G. The Inappropriateness of the International Context}

Not only was the Court's decision to apply the Convention to the sub-

74. International sea law limits rights to ocean space to certain kinds of rights, which may be exercised differentially as to different competing parties. See United States v. Louisiana, 363 U.S. 1, 34 (1960) (various sorts of maritime boundaries may be asserted for different kinds of jurisdictional claims); cf. Advisory Opinion on the Western Sahara, [1975] I.G.J. 12, 68 (describing differences between ties of territorial sovereignty and rights relating to land).

75. See p. 1655 supra. The 200-mile exclusive economic zone likely to emerge from the Third United Nations Conference on the Law of the Sea approves claims by the United States and other nations over resources within 200 miles of the coastline. See note 19 supra.

76. See note 16 supra.

77. See United States v. Louisiana, 394 U.S. 11, 18-19 (1969) (Louisiana III). The Commandant of the Coast Guard drew inland water lines off the Louisiana coast in 1953. In Louisiana III, the state urged acceptance of those lines to demarcate its coastline under the Submerged Lands Act. The Court rejected the proposal. Id. at 20-21.

78. See Report of the Special Master at 11, United States v. California, 447 U.S. 1 (1980).

79. United States v. California, 381 U.S. 139, 166-67 (1965).

80. Id. at 167. The conclusion demonstrates the weakness of the Court's argument that setting a federal-state boundary necessarily had international implications. The Court offered a second reason for this unexpected holding: it asserted that a stable boundary would allow for stable expectations. Id. at 166. This argument against an ambulatory boundary was disingenuous because the Court held that natural or artificial modifications of the shoreline would change the legal baseline. Id. at $139,166$. 
merged lands cases unnecessary, it was also inappropriate and potentially mischievous. The provisions of the Convention include codifications of customary international law that have grown over centuries of use and misuse of ocean space by the world's nations. These rules, designed for application in an international setting, are not well suited to the resolution of national disputes. ${ }^{81}$ The goals in designing rules to delimit ocean space in the international context include preserving sovereign rights, ${ }^{82}$ accommodating national security concerns, ${ }^{83}$ achieving fair and efficient allocation of resources, ${ }^{84}$ and finding solutions readily applicable to socially, politically, and geographically diverse nations. ${ }^{85}$

These substantive goals reflect the limitations of legal process in the world community. ${ }^{86}$ The most important constraint affecting the international order is its inability to prevent strong states from usurping the rights of weaker ones. Nations cannot bring legal action against each other without their mutual consent, ${ }^{87}$ and no tribunal has power to enforce its decisions. ${ }^{88}$ Therefore, courts may tend to give more attention to the likelihood that the parties will obey a particular decision than to the most just and efficient resolution of the actual dispute. ${ }^{89}$

In the domestic context, the philosophical underpinnings and legal institutions of American federalism encourage the realization of goals different from those pursued in resolving international disputes. The nation's basic political cohesiveness and shared values allow courts to identify and

81. Before selecting international law, domestic courts should ascertain that international law fits the particular case to which it is being applied. See generally Nanda, Applications of Customary International Law By Domestic Courts: Some Observations, 12 N.Y.L.F. 187 (1966).

82. National sovereignty involves the power of a nation to act independently. That power is restricted by the imposition of international law. Among the rights considered fundamental to national sovereignty are the right to control internal, domestic matters; the power to admit or expel aliens; diplomatic privileges abroad; and jurisdiction over crimes committed on national territory. See J. STARKE, supra note 1 , at 114 .

83. M. MCDOUGAl \& W. BURKe, The PUblic ORder of THE OCEANS 27, 482-85, 566-67, 589. 93, 633 (1962) (describing security interests of maritime nations).

84. National notions of just resource allocation depend heavily on particularistic interests, including security and sovereignty. A nation's representatives in international forums will tend to argue with these interests in mind. Further, an efficient allocation of resources cannot be implemented unless the first two goals are attained, thereby making the plan acceptable to sovereign nations.

85. See M. MCDOUGAL \& W. BURKE, supra note 83, at 15-16 (describing diverse participants affected by international sea law).

86. Cf. E. MCWHINNEY, FEDERAL CONSTITUTION MAKING FOR A MULTI-NATIONAL WORLD 112-27 (1966) (criticizing feasibility of world federalism because federal systems are only viable when they rest upon "substantial consensus" as to basic values and goals).

87. See H. LAUTERPACHT, THE DEVELOPMENT OF INTERNATIONAL LAW BY THE INTERNATIONAL COURT 338 (1958) (jurisdiction of international courts depends on agreement of parties); McDougal, The Impact of International Law Upon National Law: A Policy-Oriented Perspective, 4 S.D. L. REV. 25, 52-57 (1959) (discussing effect on international legal system of need for consent of parties to confer competence on international tribunals).

88. See J. STARKE, supra note 1 , at 34-35.

89. Cf. H.L.A. HART, THE CONCEPT OF LAW 209 (1969) (considering whether international law is really law). 
enforce a wide range of policies in federal-state disputes without endangering their own legitimacy. ${ }^{90}$ In designing offshore boundaries between the states and the federal government, courts need not focus on security concerns. Rather, the major policy considerations include the allocation of resources and the protection and development of coastal areas.

Furthermore, the limitations of the international legal process are not present in the domestic context. The institutional features of the federal system facilitate the pursuit of a wide range of goals. First, there is an effective process for the design and promulgation of law by Congress."1 Second, the states and the federal government may sue each other. ${ }^{92}$ Third, the compelling power of judicial orders is almost universally enforced ${ }^{93}$ and respected.94

The federal system also affords protections to both levels of government. These protections limit the types of abuses that threaten the international order. The federal government has power over states by virtue of the supremacy clause. ${ }^{95}$ State lands are not immune from a federal taking, given proper congressional authorization; ${ }^{96}$ federal legislation under vari-

90. See Friedlich, The Political Theory of Federalism, in FEDERALISM AND SUPREME CouRTS AND THE INTEGRATION OF LEGAL SYSTEMS 35 (E. McWhinney \& P. Pescatore eds. 1973).

91. See U.S. CONST. art. I (setting out powers and institutional features of Congress).

92. 28 U.S.C. $\$ 1251(b)(2)$ (1976) (Supreme Court has original, but not exclusive, jurisdiction over controversies between states and federal government). A state may be sued by another state or by the United States without the consent of the defendant state. United States v. Texas, 143 U.S. 621 (1891). Neverthless, a state must obtain the consent of the federal government to sue that government. Kansas v. United States, 204 U.S. 331 (1907). In this latter regard, the national and international situations are formally similar. The difference is social and political rather than legal.

93. See Cooper v. Aaron, 358 U.S. 1, 18 (1958) ("[T]he federal judiciary is supreme in the exposition of the law of the Constitution, and that principle has ever since [Marbury $v$. Madison] been respected by this Court and the Country as a permanent and indispensable feature of our constitutional system."); G. GUNTHER, CASES AND MATERIALS ON CONSTITUTIONAL LAW 32-34 (9th ed. 1975) (discussing authority of Supreme Court's interpretation of Constitution).

The practical consequences of the organizational differences between the United States and the international legal systems are highlighted by a comparison of Brown v. Board of Educ., 347 U.S. 483 (1954), with the recent decision of the International Court of Justice concerning United States diplomatic and consular personnel held hostage in Iran. Case Concerning United States Diplomatic and Consular Staff in Tehran (United States v. Iran), reprinted in 19 INT'L LEGAL MATERIALS 553 (1980). In Brown, the questions at issue and the character of the Court's decision were controversial. The Court's desegregation decision, however, was ultimately respected as the supreme law of the land. See A. BICKEL, THE LEAST DANGEROUS BRANCH 244-72 (1962) (discussing history of school segregation cases after 1954). In the Iranian hostage case, the International Court of Justice held that Iran violated international law when American diplomatic and consular staff in Tehran were seized and held hostage. Case Concerning United States Diplomatic and Consular Staff in Tehran (United States v. Iran), reprinted in 19 INT'L LEGAL MATERIALS, 553, 574 (1980). Although the holding was not controversial, it was not obeyed. See N.Y. Times, May 25, 1980, § A, at 1, col. 6 (quoting Iranian officials stating that decision was without meaning).

94. See M. MARCUS, TRUMAN AND THE STEEL SEIZURE CASE 197 (1977) (executive respected Court order in Youngstown Sheet \& Tube Co. v. Sawyer, 343 U.S. 579 (1952), invalidating presidential seizure of steel mills, even though order invalidated major executive policy decision).

95. U.S. CONST. art. VI, cl. 2.

96. See Oklahoma v. Guy F. Atkinson Co., 313 U.S. 508, 534 (1941) (federal government has power to take state property by eminent domain for congressionally authorized flood control project). 
ous constitutional provisions, including the commerce clause, ${ }^{97}$ can preempt state regulation in the same field ${ }^{98}$ and federal courts have exclusive jurisdiction in all admiralty and maritime cases. ${ }^{99}$ On the other hand, the states retain powers not given by the Constitution to the federal government or denied to the states. ${ }^{100}$ The relative significance of the powers accorded states and the federal government has shifted over time, ${ }^{101}$ but the basic structure of the federal system has remained stable. ${ }^{102}$

These differences in policy and institutional structure matter to the submerged lands controversy in concrete ways. For example, in California II the Court held that future natural or artificial modifications of the shoreline would change the location of the baseline. ${ }^{103}$ Such an ambulatory boundary may be necessary in the international context in order to guarantee national security by providing protection for coastal and offshore structures and installations. National security, however, is not a useful criterion for determining whether there should be an ambulatory boundary between federal and state lands; an ambulatory boundary in the domestic context can only be justified by domestic concerns. ${ }^{104}$

97. U.S. CONST, art. I, § 8, cl. 3.

98. See, e.g., City of Burbank v. Lockheed Air Terminal, Inc., 411 U.S. 624 (1973) (state and local control over aircraft noise preempted by federal regulatory schemes); Pennsylvania v. Nelson, 350 U.S. 497 (1956) (Smith Act, prohibiting knowing advocacy of overthrow of government, preempted Pennsylvania state sedition law).

99. U.S. CONST. art. III, $\S 2$; see 28 U.S.C. $\S 1333$ (1976) (giving district courts original jurisdiction in all admiralty and maritime cases, but "saving to suitors in all cases all other remedies to which they are otherwise entitled").

100. U.S. CONST. amend. X. The Court recognized the substantial scope of state sovereignty in National League of Cities v. Usery, 426 U.S. 833 (1976) (Congress cannot set maximum hours and minimum wages for state and municipal employees because Tenth Amendment limits commerce power).

101. The Court under Ghief Justice Marshall emphasized national supremacy. M. REAGAN, THE NEW FEDERALISM 19 (1972). Later, from the Taney Court to the mid-1930s, the Court viewed states and the federal government as more equal in authority and power. Id. at 19; see E. CORWIN, THE TWILIGHT OF THE SUPREME COURT 50 (1934) (characterizing this rough parity as "dual federalism"). After the New Deal in a period described by commentators as "cooperative federalism," federal-state cooperation was not restrained by the notion that state powers limited national powers

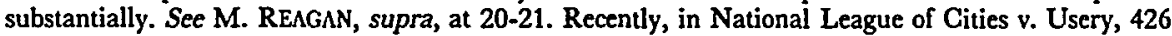
U.S. 833 (1976), the Court has limited federal powers as against the states. See note 100 supra.

102. See Corwin, The Passing of Dual Federalism, 36 VA. L. REV. 1, 3 (1950) (stable structural features of federal system include: (1) written Constitution as "supreme law," (2) union of states for common ends, (3) sharing of legislative powers between states and federal government, (4) operation of each government unit within area of assigned authority upon people and property in its territorial limits, (5) law enforcement provision for each center of government, (6) judicial review of legislative and executive acts, and (7) method of constitutional amendment which gives states deciding role).

103. United States v. California, 381 U.S. 139, 177 (1965). The Court did preclude future changes in international law from changing the coastline for purposes of the Submerged Lands Act. See p. 1661 supra. It distinguished the two contexts by arguing that natural modifications of the shoreline were unlikely to lead to more than "relatively slight and sporadic changes" in the legally defined baseline. 381 U.S. at 177. But see Morgan, Louisiana's Changing Shoreline, in OIL AND GsS OPERATIONS: LEGAL CONSIDERATIONS IN THE TIDELINES AND ON LANDS 66, 78 (R. Slovenko ed. 1963) (Louisiana's coastline can shift quickly and substantially).

104. See Krueger, The Background of the Doctrine of the Continental Shelf and the Outer Conti- 
The differences in institutional structure between the international and domestic contexts also affect the types of solutions best suited to each setting. Comparatively mechanical solutions, which do not require wide interpretive flexibility, are appropriate in the international context. ${ }^{105}$ More flexibility can be allowed in the domestic setting because the nation's institutional structures facilitate resolution of disagreements about the interpretation of laws or policies and the enforcement of such determinations.

\section{Results of Selection of International Law}

The application of international law in a domestic context can generate problems in international law as well as in domestic policy. Inescapably, judicial interpretation of international law is influenced by some of the distinctive demands of the domestic context and ignores factors that would be pertinent in a truly international dispute. The result is a misleading contribution to the body of international legal precedent.

\section{A. Distortions of International Rules}

The Supreme Court's submerged lands decisions have a significant effect on the international legal system because no single court has authority to interpret international law definitively. ${ }^{106}$ Courts involved in the process of making and using international law, including international and domestic courts, rely on each other for precedent. ${ }^{107}$ International legal decisions "are not merely evidence of existing law; they often become the creators of law, especially customary law, by becoming part of international practice."108 Because the international legal order depends in part upon the effective use of national legal systems, ${ }^{109}$ any court presuming to interpret international law must understand that it is a potential maker of

nental Shelf Lands Act, 10 N $\mathrm{T}$. RESOURCES J. 442, 462-63 (1970) (ambulatory federal-state boundary that is identical with international boundary of nation can pose problems for United States Corps of Engineers in considering applications for construction of offshore structures). Compelling interests other than those that operate in the international context may justify an ambulatory boundary in the domestic setting. Nevertheless, the justifications and consequences of a changing boundary in the two contexts are different, and those differences should be recognized so that courts can decide the question appropriately.

105. See TAN 81-85 supra (listing goals in designing international rules).

106. See note 1 supra (international judicial bodies lack permanent jurisdiction to make binding decisions).

107. See W. LEVI, CONTEMPORARY INTERNATIONAL LAW 53 (1979). Courts participating in making international law include international courts (such as the International Court of Justice), national courts (such as the United States Supreme Court), arbitration tribunals (such as the BritishAmerican Mixed Claims Tribunal), and international military courts (such as the International Military Tribunal at Nuremberg).

108. Id.

109. Sce R. FALK, THE ROLE OF DOMESTIC COURTS IN THE INTERNATIONAL LEGAL ORDER 2427 (1964). 
precedent. $^{110}$

\section{B. Judicial Deference and Estoppel}

By framing the submerged lands cases in terms of international law, the Court set the stage for granting undue judicial deference to the position of the executive in federal-state boundary disputes. ${ }^{111}$ The Court deferred to the executive on the ground that the conduct of foreign affairs is the executive's responsibility. ${ }^{112}$ As a result, the federal government has raised irrelevant foreign policy concerns as ploys to obtain a division of the submerged lands more favorable to its interests, ${ }^{113}$ even when the resulting coastline would not in fact be drawn with international concerns in mind.

For example, the Court has deferred to the executive on the question of whether or not to draw straight baselines along jagged parts of the nation's coast, ${ }^{114}$ as the Convention permits. ${ }^{115}$ Louisiana's shore, for example, is fringed with islands ${ }^{16}$ and thus meets an express criterion in the Convention for the use of straight baselines. Although drawing straight baselines would, in general, expand the territorial sea, the executive branch has chosen not to do so. This decision was aimed at limiting state ownership rather than at foreign policy objectives. Despite Louisiana's claim that the federal government would use straight baselines in the Mississippi Delta were it not for the submerged lands litigation, ${ }^{117}$ the Court accepted the federal government's position, invoking executive responsibility for "the formulation and implementation of foreign policy."118

Another consequence of using the same baseline for domestic and international purposes is that the United States might be estopped ${ }^{119}$ or embar-

110. See J. STARKE, supra note 1 , at 55-56.

111. Deference to the executive may mean deference to a position espoused by the federal government in the course of the litigation or deference to a position the executive branch has taken over time vis-a-vis other nations.

112. See Charney, supra note 8 , at $413-46$ (describing variation in judicial deference to executive in submerged lands cases depending on particular issue).

113. See note 49 supra.

114. See United States v. California, 381 U.S. 139, 167-69 (1965).

115. According to the Territorial Sea Convention art. 4, para. 1:

In localities where the coastline is deeply indented and cut into, or if there is a fringe of islands along the coast in its immediate vicinity, the method of straight baselines joining appropriate points may be employed in drawing the baseline from which the breadth of the territorial sea is measured.

Article 4 codifies the decision of the ICJ in The Fisheries Case (United Kingdom v, Norway), [1952] I.C.J. 116.

116. United States v. Louisiana, 394 U.S. 11, 72 (1969).

117. Id.

118. Id. at 73 .

119. Estoppel has been invoked in international legal proceedings in a variety of contexts. See, e.g., Arbitration Between Great Britain and Costa Rica, Oct. 18, 1923, 18 AM. J. INT'L L. 147, 157 (1924) (Taft, Arb.) (proceeding under treaty of arbitration) (recognizing place of equitable estoppel in international affairs). 
rassed $^{120}$ in an international arena if it attempted to claim other boundaries off its own coast or to assert other interpretations of the Convention in the delimitation of any coast. ${ }^{121}$

The Court has traditionally exercised judicial deference in cases involving international boundary delimitations. ${ }^{122}$ But the tendency to defer to the executive, as well as the problem of estoppel, could be avoided if the Court treated these cases as exclusively domestic disputes. ${ }^{123}$

\section{What Is to Be Done?}

The Supreme Court or Congress should rectify the mistaken application of the Convention to the submerged lands cases. One resolution of the domestic controversy from a policy perspective concerned with effecting a maximally efficient division of resources between the parties would be for Congress to reject the use of baselines altogether in the domestic setting. Allocation of resources could instead be based on a reasoned division of rights and responsibilities between the federal government and coastal states. Alternatively, if Congress does not amend the Submerged Lands Act, the Court could reject the convention as irrelevant and troublesome to a successful resolution of the domestic dispute. Nevertheless, given that the parties have come to rely on the decisions demarcating a coastal boundary between state and federal submerged lands, the Court may not want to make a rapid transition to new methods of resource allocation.

\section{A. Preserving Continuity with the Past: The Convention as a Con- venient Source of Law}

Even if the Court treats the submerged lands cases as purely domestic controversies, it need not ignore the rules codified by the Convention, but can preserve some continuity with prior submerged lands decisions. When the Court first adopted the Convention in the submerged lands cases in 1965 , it described the treaty as containing "the best and most workable

120. See Charney, supra note 8 , at 449 (United States could not easily espouse positions in negotiations with foreign nations contrary to positions taken by Supreme Court).

121. Cases in which estoppel arguments might be made could involve questions concerning rights of warships to travel in offshore areas, the right to lay mines, and the exclusive right to claim ocean areas for fishing. See id. at 450 n.215 (United States protests foreign claims concerning historic bays and straight baselines).

122. In an early case involving questions about the sovereignty of the government of Buenos Aires over the Falkland Islands, the Court deferred absolutely to the executive's position. Williams v. Suffolk Ins. Co., 38 U.S. (13 Pet.) 415 (1839). The Court has exercised judicial deference in other cases involving questions of territory. See, e.g., Foster v. Neilson, 27 U.S. (2 Pet.) 253 (1829) (question of valid chain of title to land in West Florida); Charney, supra note 8, at 407-12 (noting types of situations where court tends to defer to executive).

123. See Charney, supra note 8 , at $412-13,454$ (identifying factors for courts to consider before exercising judicial deference). 
definitions available." 124 Admittedly, many of the rules in the Convention give useful direction for demarcating coastal boundaries. The Court seemed to assume, however, that the Convention's guidance could only be invoked if it were made a binding source of law. The Convention, however, might be relied on as merely a suggestive source of law in the submerged lands cases. ${ }^{125}$ Because the Convention's rules are not always appropriate within the context of the federal-state dispute, courts should be free to consider other solutions that would be more equitable and sensitive to policy considerations.

\section{B. Breaking with the Past: Political Solutions}

Setting these cases in an international frame has discouraged legislative or other political solutions to the dispute. Congress may be inhibited in devising a political solution that would take account of relevant domestic facts because the Court has treated the definition of inland waters as a question of international law.

Commentators have proposed several types of political solutions. ${ }^{126} \mathrm{~A}$ solution designed to achieve an efficient allocation of resources between the parties need not even invoke the baseline notion. Rather than resolving the controversy by delineating a physical boundary between state and federal submerged lands, Gongress could design a solution based on the interests of the federal government and the coastal states. ${ }^{127}$ The criteria for resolving the controversy in this way need not be legal. By taking advan-

124. United States v. California, 381 U.S. 139, 165 (1965).

125. The opinion in California III, United States v. California, 447 U.S. 1 (1980), hints in this direction by referring to the Convention as giving "guidance' in the definition of the term 'coast line." "Id. at 5 . Nevertheless, all the briefs and supporting materials in the case cited the Convention as binding law and assumed that delineation of an international coastline and a federal-state boundary under the Submerged Lands Act were one and the same. See, e.g., Exception of the State of California and Supporting Brief at 16-33 (principles of Territorial Sea Convention govern legal baseline under Submerged Lands Act); Reply Brief of the State of California at 6-20 (disagreeing with federal government's interpretation of Territorial Sea Convention, but agreeing that articles of that Convention govern).

126. See, e.g., 1 Public Land LaW Review Coma'N, Study of the OUTER Continental SHELF LANDS OF THE UNITED STATES $\S 12.55$ (1968) (proposing legislation by coastal states and federal government to delineate federal-state offshore boundary); 1 A. SHALOWITZ, supra note 25, at $172 \mathrm{n} .151$ (proposing agreement between parties on method of boundary delimitation to simplify leasing procedures on submerged lands); Taylor, The Settlement of Disputes Between Federal and State Governments Concerning Ofshore Petroleum Resources: Accommodation or Adjudication? 11 HARV. INT'L L.J. 358, 372, 389 (1970) (praising Australian system of negotiated agreement between states and Commonwealth Government for joint exploration and exploitation of offshore petroleum products).

127. Alternatively, the Court could appoint a Special Master to design a reasoned division of resources. A primary advantage of appointing a Special Master is comparative simplicity and clarity; one or a few experts would be able to create a coherent settlement relatively speedily. A congressional resolution, perhaps involving appointment of an interagency commission, would take longer and involve more participants, but would have the advantage of Congress' greater resources for thorough investigation and analysis of the issues. 


\section{Submerged Offshore Lands}

tage of the nation's well-established legal and political institutions, Congress could effect a creative allocation of resources permitting the protection and development of offshore areas.

Whether the Convention is rejected as law and preserved as a guide, or is rejected totally as inapplicable to the submerged lands cases, it will become possible to resolve these cases in terms relevant to the domestic context. It will also become clear to other judicial forums, whether of other nations or of international bodies, that they should not bestow the status of international law on interpretations of the Convention made by a national court in the context of an exclusively domestic controversy. ${ }^{128}$

128. Analogously, one commentator has suggested that the rules designed at the 1958 Geneva Conference for delimiting boundaries between nations may soon become obsolete because of the shift in context arising from the development of international organizations with authority over the use of ocean space. Just as rules regulating boundaries between nations are not appropriate to the regulation of boundaries between federal and state authority within a nation, they may not be appropriate to the regulation of boundaries between nations and international organizations. Laws designed for one social and political context cannot be facilely transposed to another, without the risk of producing undesirable legal and practical consequences. See Borgese, $A$ Constitution for the Oceans, in THE TIDES of ChANGE 340, 343-45 (E. Borgese \& D. Krieger eds. 1975). 